\title{
Glacial sediment and landform record offshore NW Scotland: a fjord-shelf-slope transect through a Late Quaternary mid-latitude ice-stream system
}

\author{
T. BRADWELL ${ }^{1,2 *}$, M.S. STOKER ${ }^{1}$ \\ ${ }^{1}$ British Geological Survey, West Mains Road, Edinburgh, EH9 3LA, UK \\ ${ }^{2}$ Biological \& Environmental Sciences, University of Stirling, FK9 4LA, UK \\ *Corresponding author (e-mail:tom.bradwell@stir.ac.uk)
}

Current estimates of ice-mass loss from ice sheets vary, but there is consensus that the rate of loss has increased over the last two decades, from $\sim 100 \mathrm{Gt} \mathrm{yr}^{-1}$ to $\sim 400 \mathrm{Gt} \mathrm{yr}^{-1}$, with the great majority occurring within ice-stream systems (e.g. Shepherd et al. 2012; Hanna et al. 2013). Where ice streams terminate in open-marine settings large volumes of ice are discharged into the oceans via calving, as currently seen in Pine Island Bay, West Antarctica, or at Jakobshavn Isbrae, West Greenland. At the Last Glacial Maximum (LGM) an ice sheet covered more than two thirds of the British Isles (50-61 ${ }^{\circ} \mathrm{N}$ ) and reached onto the continental shelf, in places extending to the shelf edge in the west (Gibbard \& Clark 2011; Clark et al. 2012). In this contribution we summarise the Pleistocene sediment and landform record of a large mid-latitude ice stream that once drained the NW sector of the British-Irish Ice Sheet (BIIS). Drawing on marine geophysical and geological data from the NW UK continental shelf collected over four decades, we describe the main elements of the system along a transect stretching over $300 \mathrm{~km}$ - from the heads of the fjords to beyond the shelf slope. The work draws largely on previously published research (Stoker et al. 1993, 2006, 2009, 2010; Stoker \& Bradwell 2005; Bradwell et al. 2007, 2008a, b; Bradwell \& Stoker 2015a, b), but includes some new insights and interpretations.

The bedrock geology of NW Scotland and the Hebrides Shelf is structurally complex and lithologically diverse. Unsurprisingly, the geological structure imposes a general first-order control on the topography of the region, with resistant upstanding Precambrian rocks typically forming the extant landmasses and bathymetric highs, and the weaker Mesozoic cover rocks flooring bathymetric troughs and low-lying shelf regions (Stoker et al. 1993; Fyfe et al. 1993). The geography of NW Scotland and the adjacent UK continental shelf has been shaped by successive glaciations since at least $\sim 0.44 \mathrm{Ma}$ and probably since $\sim 2.6 \mathrm{Ma}$ BP (Stoker et al. 1993; Thierens et al. 2012). The result is over $1 \mathrm{~km}$ of vertical relief with strongly dissected mountainous terrain, u-shaped valleys, overdeepened offshore rock basins and a deeply indented fjordic coastline. The deeper waters of the Minch, a wide structurally controlled bathymetric trough (half-graben), extend onto the continental shelf as a broad, 30-40 km wide, NW-trending channel, defined mainly by the $100 \mathrm{~m}$ isobath (Fig. 1b). The continental shelf is relatively wide around NW Scotland (50-150 km) with the shelf break at approximately the $200 \mathrm{~m}$ isobath, beyond which the shelf slope descends to over $1000 \mathrm{~m}$ at an angle of $2-4^{\circ}$. The seabed topography of the Hebrides Shelf and the Minch is highly variable, with numerous overdeepened basins, shallow banks, and steep-sided islands; hence, the overall shelf bathymetry does not simply deepen with distance offshore. Of particular note are nearshore bathymetric deeps in Inner Sound, around the Summer Isles, and in the sea lochs (fjords) where water depths $>200 \mathrm{~m}$, and exceptionally $>300 \mathrm{~m}$, are encountered (Fig. 1). The submarine sediments and landforms described here are the product of ice sheet growth and decay over the last glacial cycle (Marine Isotope Stage 2-3) as well as previous glaciations during the Mid to Late Pleistocene.

\section{Description of fjord to shelf-slope landforms}

Fjords

The seaboard of NW Scotland is a classic fjord landscape with long deep inlets (or sea lochs) and steep protruding headlands. The longest fjords extend 10-30 km from the contiguous coastline, are up to $10 \mathrm{~km}$ wide and commonly exceed $100 \mathrm{~m}$ water depth along their central axes. The fjords form an arborescent network of tributary valleys branching off the main trunk valley - the bathymetric trough of the Minch, itself a large scale fjord, 40-50 km wide and $150 \mathrm{~km} \mathrm{long.} \mathrm{All} \mathrm{the} \mathrm{fjords} \mathrm{have} \mathrm{steep-sided} \mathrm{walls,}$ which decrease in gradient downslope, and smooth broad floors, defining a characteristic u-shaped cross profile (Fig. 1c). The fjord morphology is similar, but with lower relief, to the fjord systems of West Greenland (Dowdeswell et al. 2014).

The following description concentrates on Little Loch Broom - an exemplary glacial fjord - where good multibeam echosounder (MBES) bathymetry coverage exists and several marine geological studies have examined its sediment archives, glacial stratigraphy and paraglacial history (Stoker et al. 2006, 2009, 2010). Little Loch Broom is a NW-trending sea loch, $12 \mathrm{~km}$ long and 0.5 to $2.0 \mathrm{~km}$ wide (Fig. 1c). It is divided approximately at its mid-point into inner and outer basins by a mid-loch bedrock sill ( 25 $\mathrm{m}$ below sea level). The loch is deepest in its inner basin $(119 \mathrm{~m})$, while the outer basin reaches a maximum depth of $65 \mathrm{~m}$ (Stoker et al. 2006). Slope angles are steep in both the inner loch (locally $>50^{\circ}$ ) and outer loch (locally up to $30^{\circ}$ ). Seismic profiles show that Little Loch Broom is floored by a significant thickness of Quaternary sediment, typically between 40-100 m but locally up to $160 \mathrm{~m}$ thick (Stoker et al. 2006, 2009).

Although the seafloor of the inner basin is generally smooth, with occasional pockmarks, the outer basin is more complex geomorphologically. Four main areas of disturbed, irregular seabed have been identified in Little Loch Broom (Stoker et al. 2006, 2010). Based on surface morphology, acoustic signature and geological-core evidence these areas have been mapped as submarine 
mass movements or slides. Three of these slide complexes are in the outer basin (Rireavach, $1.0 \mathrm{~km}^{2}$; Scoraig, $0.25 \mathrm{~km}^{2}$; Carnach, $0.1 \mathrm{~km}^{2}$ ) whilst one is on the distal flank of the inner basin (Badcaul, $0.9 \mathrm{~km}^{2}$ ) (Fig. 1c-e). The slides are characterised by large diffuse zones of seafloor disturbance, typically in water depths of 30 to $100 \mathrm{~m}$, often comprising bathymetric terraces with irregular or scalloped backscarps stepping down into the basin (Fig 1e, inset). The internal seismic reflection of these disturbed 'slide-mass' units is mostly structureless or chaotic, but with occasional discontinuous sub-planar reflectors imparting a large-scale tabular structure to the depositional package (Stoker et al. 2010). Gently curved, smaller scale, concave-up, slide surfaces are also observed within the slide complex, along with some rotation of reflections into the slope (including the seafloor). Two prominent transverse ridges occur within the fjord; one on the sill at the mouth of the loch and one on the mid-loch sill dividing the inner and outer basins (Fig. 1c). The inner ridge is $10-20 \mathrm{~m}$ high and $100-200 \mathrm{~m}$ wide; the outer ridge is $30-40 \mathrm{~m}$ high and $250-600 \mathrm{~m}$ wide. Both ridges are arcuate features in plan form, with asymmetric cross profiles and undulating long profiles - typical of ice-contact sedimentary landforms (i.e. moraines) (Benn \& Evans 2010).

\section{Cross-shelf trough (The Minch)}

The waters of the Minch separate mainland Scotland from the Outer Hebrides (Fig. 1b). This broad bathymetric trough is ca. $50 \mathrm{~km}$ wide and $300 \mathrm{~km}$ long and extends across the continental shelf as a NW-trending deeper-water corridor defined by the $100 \mathrm{~m}$ isobath. Water depths vary considerably within the inner parts of the Minch, with rugged bedrock highs generally separated by smoother seabed lows with thin sediment cover $(<30 \mathrm{~m})$. Several Tertiary igneous intrusions stand proud of the seabed, most notably the Shiant Islands, $15 \mathrm{~km}$ E of Harris; whilst the deepest bathymetry is the N-S oriented narrow basin east of Raasay where water depths exceed $300 \mathrm{~m}$. The predominant landforms imaged in singlebeam and MBES are tapering streamlined features, in bedrock and soft sediment, typically on a scale range $10^{2}$ to $10^{3} \mathrm{~m}$; most are orientated along the trough axis, although local orientation trends are common where bathymetric relief is greater.

Around $58^{\circ} \mathrm{N}$ a well-preserved suite of streamlined landforms exist in an area of discontinuous sediment cover around a broad bedrock high (East Shiant Bank) in present-day water depths of 40-70 m (Fig. 1b). In the southern half of the area are numerous ( $>50)$ elongate streamlined mounds with equant, elliptical or cigar-shaped planform and broad poorly defined crestlines (Fig. 2a, b). The mounds range in length from 250 to $1300 \mathrm{~m}$, in width generally from 200 to $400 \mathrm{~m}$; and in height from 5 to $15 \mathrm{~m}$. Elongation ratios (length/width) are typically between 1.5 and 4. Most of the sediment landforms north of $58^{\circ} 01^{\prime} \mathrm{N}$ are linear narrow ridges with streamlined tapering planforms and long profiles (Fig. 2a). These ridges range in length from $400 \mathrm{~m}$ to $1500 \mathrm{~m}$, and in width generally from $100 \mathrm{~m}$ to $300 \mathrm{~m}$. Elongation ratios range from 4 to 14, and most ridges show a distinct long profile decrease in height. The seabed ridges in the extreme north of the image appear to have bedrock at their highest point (southern ends) forming large crag-and-tails, but are only partially captured by the MBES data (Fig. 2a). Other pronounced streamlined ridge and groove features are seen elsewhere in the Minch (Fig. 2c). These lineations have subtle seabed expression with typical amplitudes of only 3-5 m from crest to trough and lengths typically between 500 to $2000 \mathrm{~m}$. Where Pleistocene/Holocene sediment cover is patchy or absent, across much of the inner shelf, bedrock crops out on the seafloor. When examined in detail, many of these bedrock outcrops also have streamlined morphology, on a scale of $10^{1}$ to $10^{2} \mathrm{~m}$, with an elongate teardrop-shaped planform and tapering (N-S) height profile (Fig. 2a-c).

Single-beam and MBES bathymetry have identified conspicuous arcuate seabed ridges, in water depths of between 40 and 90 m, fronting the main fjords and large bays of NW Scotland (Stoker et al. 2006, 2009; Bradwell et al. 2008b; Bradwell \& Stoker 2015a, b). These ridges range in morphology and internal architecture. The largest feature is the arcuate Eddrachillis Ridge, which reaches $35 \mathrm{~m}$ in height, $1000-2000 \mathrm{~m}$ in width and is over $20 \mathrm{~km}$ in length. Seismic-reflection profiles shows it is comprised of a generally chaotic to acoustically transparent unit with very few internal structures unconformably deposited on underlying strata (Bradwell \& Stoker, 2015b). A similar-sized ridge complex - 1-2 km wide, up to $30 \mathrm{~m}$ high and at least $15 \mathrm{~km}$ long - is seen stretching from the mouth of Loch Ewe to near Greenstone Point and forming a long broad arc open to the SE. When merged with existing MBES data (Stoker et al. 2006), new MBES data from the eastern Minch show the detailed geomorphology of this substantial sedimentary feature (Fig. 2d), as well as the delicate superimposed ridges (1-5 m high; $<100 \mathrm{~m}$ wide) - the whole complex being akin to ice-contact subaqueous landforms seen elsewhere (Benn \& Evans 2010).

Superimposed on the glacial landform record in places are numerous, largely straight but occasionally sinuous, furrows describing cross-cutting irregular patterns (Fig. 2e). These well-preserved furrows are typically between 500-2000 m long, between 50-200 m wide but rarely more than $2 \mathrm{~m}$ deep. There is a weak positive correlation between furrow length and width. Furrows are most abundant on nearshore banks in the Minch within a well-defined (present-day) water depth range of around 70-90 $\mathrm{m}$ and are rare below $120 \mathrm{~m}$.

\section{Mid shelf, outer shelf and slope}

The outermost shelf and continental slope around NW Scotland constitute an important sedimentary archive for Pleistocene environmental change in the NE Atlantic (Fig. 3). Generally, the Pleistocene geology on the continental shelf takes the form of a landward stacking succession of sediments younging from the shelf break to the Minch (Fig. 3d) (Fyfe et al. 1993; Stoker et al. 1993). However, locally thicker glacigenic sediment sequences are seen in overdeepened mid-shelf basins. Key BGS boreholes on the mid and outer Hebrides Shelf have penetrated stacked sequences of glacial diamictons (Stoker et al. 1993), as well as thick glaciomarine deposits, and proximal (coarse-grained) proglacial sediments (Fyfe et al. 1993). Where the cross-shelf trough ends NW of Lewis, the shelf break bulges conspicuously outwards at the Sula Sgeir Fan (Fig. 3a, b). This large $\sim 3750 \mathrm{~km}^{2}$ wedgeshaped sediment package on the continental slope comprises laterally continuous, slope-parallel, sheet-like diamictons and poorly sorted sediments of Pleistocene age (Stoker et al. 1993; Stoker 1995). Although MBES data is lacking for the depocentre, good singlebeam echosounder bathymetry (Olex dataset) and seismic first-return data show a network of large, subparallel, occasionally cross-cutting furrows and channels (Fig. 3c). Most channels descend the whole length of the imaged slope, a distance of ca. $20 \mathrm{~km}$; are relatively wide compared to their depth; have sharply defined margins and box-shaped cross-sections. Discrete lobate forms, up to $5 \mathrm{~km}$ wide, occur along the foot of the slope many being the downslope termination of one or more channels. 
At several places on the outer shelf large sedimentary ridge complexes have been identified traversing the cross-shelf trough (Stoker \& Bradwell 2015b). The largest occur close to the shelf break, in present-day water depths of $\sim 200 \mathrm{~m}$. These long broad sediment ridges are up to 20-30 m high and 2 to $4.5 \mathrm{~km}$ wide with low-angle slopes and wide poorly defined crestlines. BGS seismic profiles and singlebeam echosounder bathymetry show the longest ridge, near the shelf break, to be in excess of 50 km (Stoker et al. 1993; Bradwell et al. 2008a). Further inshore on the mid shelf, two other large sediment ridges of similar size and morphology have been mapped from single-beam and MBES data (Bradwell \& Stoker 2015b): one ridge connects the Butt of Lewis to the Sula Sgeir high, and the other extends N then E from the Butt of Lewis almost perpendicular to the axis of the crossshelf trough (Fig. 3b). All of these large seabed ridges have strong affinities with features mapped elsewhere as morainal banks or ice-contact sedimentary landforms (i.e. grounding-zone wedges or subaqueous moraines) (e.g. Ó Cofaigh et al. 2003; Dowdeswell et al. 2014).

\section{Interpretation of fjord-shelf-slope landforms}

Fjords

Glaciers have carved and shaped the deeply indented fjordic coastline of NW Scotland over the last 0.5 Ma or more. Recent marine mapping has enabled a much better understanding of the submarine fjord landscape, its geology, sedimentary architecture and mass movement history (Stoker et al. 2009, 2010). The thick deglacial sediment record, exemplified in Little Loch Broom, suggests glacimarine and ice-contact sedimentation have been the major depositional environments, whilst para/postglacial slope instability and mass movement processes have reworked and significantly modified the seabed topography (Fig. 1c, d, e) (Stoker et al. 2009, 2010). The bulk of the sediment fill comprises MIS 2-stage ice-contact, ice-proximal and ice-distal glacimarine facies, assigned to the Assynt Glacigenic and Annat Bay formations (Stoker et al. 2009). Cosmogenic-isotope surface-exposure ages of boulders from onshore moraines, combined with micropalaeontological analysis and AMS radiocarbon dating of marine shells in seabed sediment cores, suggest that the whole Assynt Glacigenic Fm deglacial sequence was deposited between ca. 15 and 13 ka BP, i.e. during the Lateglacial Interstadial (Bradwell et al. 2008b; Stoker et al. 2009). However, this chronology has recently been questioned and recalibrated (yielding 5-10\% older ages; Ballantyne \& Stone 2012).

Mass-movement processes have clearly played a major role in shaping the seabed geomorphology of the fjords of NW Scotland, as in other deglaciated fjords worldwide (e.g. Syvitski \& Shaw 1995; Hjelstuen et al. 2009). Sub-bottom seismic profiles show large (10-12 m thick) debris lobes have accumulated at the base of slopes, some can be traced beneath Holocene sediments for up to $800 \mathrm{~m}$ along profile (Stoker et al. 2010). Although undated, it is likely that the whole Badcaul Slide complex in Little Loch Broom (Fig.1e) failed during, or soon after, deglaciation possibly triggered by the removal of ice support. The wider assemblage of mass movement features in the fjords are part of ongoing paraglacial landscape/seafloor readjustment in NW Scotland - the geomorphic response to changing stress conditions in glacially deposited slope sediments within glacio-isostatically loaded basins.

\section{Cross-shelf trough}

The presence of well-developed strongly streamlined landforms on the seafloor in the Minch indicate powerful erosional sculpting, sediment deformation and deposition beneath a fast-flowing ice stream, over one or more glacial cycles. The main N-S directed flow set seen in the MBES data (Fig. 2a-c) corroborates the ice-sheet flow direction derived independently from terrestrial evidence and previously acquired marine data (Stoker \& Bradwell 2005; Bradwell et al. 2007). Bedrock-dominated crag-and-tail forms are typical of upstream or ice stream onset areas where increased frictional drag, increased pressure melting, and the production of water at the bed, combine to increase erosional efficacy on the stoss side and lateral flanks of upstanding bedrock obstacles (Benn \& Evans 2010). Occasional crescentic scours around the blunt end of these crag-and-tail forms attest to this focused erosion and may be evidence of high-energy subglacial water flow. Streamlined soft-sediment features, such as drumlins, form under lower frictional drag regimes, partly by accretion and deformation (Benn \& Evans 2010; Stokes et al. 2011); whereas very long sedimentary ridge/groove forms (MSGLs) are indicative of full ice-stream velocities, probably as a result of greatly reduced ice-bed coupling (Clark 1993; King et al. 2009). The landform system preserved in the central part of the Minch (at $\sim 58^{\circ} \mathrm{N}$ ) is interpreted as a single subglacial bedform assemblage, similar to others in glaciated shelf settings (e.g. Ó Cofaigh et al. 2002; Shaw et al. 2006), with more equant drumlinoid forms in the south becoming longer and narrower, transitioning to glacial lineations in the north (Fig. 2a-c). The whole assemblage is interpreted to have formed beneath a grounded fast-flowing ice sheet corridor, and is seen as primary evidence of palaeo-ice-flow vectors at the bed of the Minch palaeo-ice stream (Bradwell \& Stoker 2015a).

Large sediment ridges fronting the fjords and deep bays of the eastern Minch are interpreted as substantial moraines or grounding-zone features, based on morphological and acoustic affinities with moraines on continental shelves elsewhere (e.g. Shaw et al. 2006; Dowdeswell et al. 2010, 2014). The more delicate superimposed ridges are interpreted as De Geer moraines associated with subsequent retreat of a (lightly) grounded marine-terminating ice sheet margin (Fig. 2b). A pene-contemporaneous connection between the large Greenstone Point moraine complex and similarly large moraines offshore Eddrachillis Bay has been made on morpho-stratigraphical grounds (Bradwell \& Stoker 2015b). All the large nearshore moraines described here are well-defined, morpho-stratigraphically equivalent features in similar water depths. Collectively they suggest a stable (long-lived?) grounded icesheet terminus position in coastal waters following ice stream demise.

Cross-cutting, irregularly distributed, well-preserved seafloor furrows in the Minch are interpreted as iceberg ploughmarks produced by keels ploughing through soft sediment. The depth and width of ploughmarks are consistent with those seen at other mid-latitude palaeo-ice sheet margins (e.g. van Landeghem et al. 2009). Their narrow water-depth distribution (70-90 m) and absence below $150 \mathrm{~m}$ indicates relatively large but uniform icebergs, whilst their state of preservation (not glacially modified) implies a relatively late (MIS-2) formation date. Taken collectively the spatial distribution pattern, density and preservation of iceberg ploughmarks in the Minch suggest that they were locally sourced and may relate to widespread calving events during the final stages of ice-sheet decay. 
Outer shelf and slope

Perhaps the most striking geological evidence for glaciation on the continental shelf is the large sediment wedge on the shelf slope - the Sula Sgeir Fan (Fig. 3a, b). Seismic studies have been used to show that the upper 100-200 m of this wedge accumulated during the Mid-Late Pleistocene largely through mass-flow processes (Fig. 3e) (Stoker et al. 1993; Stoker 1995). The location of this large discrete prograding sediment wedge at the mouth of a wide cross-shelf trough marked by several overdeepened, glacialsediment-filled, basins is entirely consistent with its designation as an ice-stream-fed trough-mouth fan (Stoker \& Bradwell 2005). Similar trough-mouth fans are found at the terminus of well-established palaeo-ice streams in numerous high-latitude settings (e.g. Vorren \& Laberg 1997; Ó Cofaigh et al. 2003). They are formed during full-glacial conditions when ice sheets advance to the shelf break, depositing large volumes of diamicton and debris-flow material in a focused zone on the shelf slope. Similarities between the surface morphology of the Sula Sgeir Fan and other well-studied trough-mouth fans indicate strong process linkages (cf. Dowdeswell et al. 2008; Gales et al. 2014). For example, the presence of lobate forms and gullies on the fan surface (Fig. 3c) suggest that glacially-fed debris flows were an important sediment delivery mechanism beyond the continental shelf break.

Further clear geological evidence for ice-sheet glaciation on the outermost UK continental shelf is seen in the suite of large seafloor ridges, interpreted as morainal banks, close to the shelf break (Stoker \& Holmes 1991; Stoker \& Bradwell 2005). Seismostratigraphic correlations place these moraines within the Mid to Late Pleistocene MacDonald Formation (Fig. 3d); although their precise age remains uncertain (Stoker et al. 1993; Stoker 2013). However, a clear process connection with the Sula Sgeir Fan has been established, with sediments on the ice-distal flank of the outermost MacDonald Fm moraines interdigitating with the uppermost mass-flow deposits of the fan (Stoker et al. 1993; Stoker 1995).

\section{Discussion: landform distribution, style of glaciation and schematic model}

It is clear from the sediment and landform record that successive mid-latitude Pleistocene ice sheets have glaciated the continental shelf to the west of Scotland (MIS 2-12) occasionally reaching the continental shelf break to the NW of the Outer Hebrides, at the Sula Sgeir Fan, and further north on the West Shetland Shelf (e.g. Stoker et al. 1993; Bradwell et al. 2008a). It is also shown from the type and pattern of subglacial landfoms that an ice stream occupied the trough of the Minch, with its tributaries channelled along fjords sourced deep in the ice-sheet interior (Fig. 1, 4). This large ice stream would have operated at key times during ice-sheet build up and decay, dominating the flow configuration of the NW sector when it did - as highlighted by the results of numerical modelling experiments (Hubbard et al. 2009). At present it cannot be demonstrated when the Minch ice stream reached the shelf edge and directly fed the Sula Sgeir Fan; although there is strong evidence that it did at key times during the Mid to Late Pleistocene (prior to MIS 10) (Stoker et al. 1993; Stoker \& Bradwell 2005), it probably did not during the last glacial cycle (MIS 2-3) (Bradwell et al. 2007; Bradwell \& Stoker 2015b). Geomorphological (end moraines), geological (glacial sediments) and seismostratigraphic (glacial erosion surfaces) evidence taken together indicate that it is very likely that the ice stream extended on to the mid shelf to the NW of Lewis during MIS2-3. Indeed new cosmogenic dating evidence from the island of North Rona, $\sim 40 \mathrm{~km}$ from the shelf edge, reinforces this view - confirming that the last ice sheet reached at least this far at the LGM, depositing boulders as it retreated ca. $25 \mathrm{ka}$ BP (Everest et al. 2013). Another key constraint relating to ice-stream decay in the NW sector of the BIIS is the biostratigraphic and radiocarbon chronology derived from marine macro- and microfauna in BGS borehole 78/4, off eastern Lewis. This detailed study showed open, cold water, conditions were present in the Minch at ca. $15 \mathrm{ka}$ cal BP, with very cold, reduced salinity, conditions persisting for some time before that (Graham et al. 1990). Between these two bracketing ages ( 25-15 ka), however, the rate, style and mechanism of ice-sheet retreat - fast vs. slow, collapse vs. incremental, grounded vs. floating - are still poorly understood.

The absence of moraines and the widespread well-preserved apparently unmodified subglacial forms (e.g. drumlins, glacial lineations) suggest that the mechanism of ice sheet decay was not by incremental grounded retreat (at least in the main trunk of the ice stream) and that the retreat process may have been rapid (Stoker \& Bradwell 2005; Bradwell et al. 2008b). In similar bathymetric settings elsewhere, where the seabed deepens inshore, the most commonly suggested style of ice-stream retreat is a non-linear one triggered by instability of the marine margin (e.g. Alley et al. 2005; Schoof 2012). This instability, brought about as grounded ice crosses the flotation threshold, leads to rapid calving, increased drawdown, dynamic thinning and thus can trigger rapid ice-stream retreat or collapse. Support for this can be found in the submarine landform record where conspicuous morpho-stratigraphically equivalent subaqueous moraines have been mapped near the present-day coastline of mainland NW Scotland in similar water depths (Bradwell \& Stoker 2015a, b). Collectively they suggest a single, stable (long-lived?) ice-sheet terminus position grounded in nearshore waters after ice-stream demise. Immediately seaward of these large moraines in the eastern Minch abundant iceberg ploughmarks, especially on banks and shallows ( $<100 \mathrm{~m}$ water depth), imply a high flux of locally sourced icebergs during the latter phase of deglaciation. Following the breakup of the Minch ice stream in MIS2, large ice-sheet outlet glaciers with tidewater margins terminated a short distance offshore (Stoker et al. 2009) with the fjords of NW Scotland serving as the main flow pathways for ice throughout much of the Pleistocene. Their wide u-shaped cross-profiles and overdeepened bedrock floors suggest that the fjords were preferentially eroded by repeated glacier occupation - prior to, during, and after ice-stream operation.

The remarkably well-preserved landform distribution in the Minch and on the continental shelf NW of Scotland is shown in Figure 4. Although high-resolution bathymetric coverage of the outer shelf is lacking, new MBES data from the central and inner parts of the Minch, show a spectrum of well-preserved Pleistocene glacial landforms on a range of scales - including streamlined bedrock forms, grooves, drumlins, subaqueous moraines, and iceberg ploughmarks. The main assemblage transition is from bedrock-dominated erosional forms on the inner shelf, through a mixture of bedrock and sedimentary forms, to an almost entirely sedimentary bed on the mid and outer shelf. A major Plio-Pleistocene depocentre occurs on the continental slope where ice streams have focused sediment in a trough-mouth fan, when eustatic sea level was significantly lower during full glacial times. The fjords, although deeply eroded bedrock troughs, also preserve thick sedimentary sequences owing to these narrow basins being the main depocentres along the quasi-stable glacial-interglacial terrestrial/marine boundary. The whole fjord-shelf-slope 
landform/sediment assemblage - exemplified in the Minch ice-stream record, offshore NW Scotland - is probably typical of midlatitude ice streams, past and present, worldwide.

\section{Figure Captions}

Figure 1. (a) Location of study area centred on The Minch, NW Scotland (red box); regional bathymetry from IBCAO v. 3.0. (b) General bathymetry and topography of NW Scotland and the surrounding continental shelf (1 km cell size DEM). Black lines show proposed flow lines of the Minch palaeo-ice stream (from Bradwell et al. 2007). The numbered red boxes and lines indicate the position of subsequent figures $(1,2,3)$. Places referred to in text are labelled. (c) Hill-shaded multibeam bathymetric image of Little Loch Broom, NW Scotland; data collected by the British Geological Survey (BGS) in 2005. Boxes show locations of (d) and (e); $x-x^{\prime}$ shows typical topographic/bathymetric cross-profile of the fjord where relief is greatest. VE $\times 4$. (d) Close-up of multibeam image showing geomorphology of mass movement features (submarine slides) in the outer basin of Little Loch Broom; y-y' shows seafloor depth profile across one of the slide complexes. VE $\times 9$. (d) Close-up of multibeam image showing seafloor geomorphology of Badcaul Slide complex in the inner basin of Little Loch Broom; z-z' shows seafloor depth profile across the mid-loch sill and slide complex. VE $\times 15$. Multibeam acquisition system Geoswath. Frequency $125 \mathrm{kHz}$. Gridcell size 5 m. Figures (1c, d, e) modified from Stoker et al. (2010).

Figure 2. (a) Hill-shaded multibeam bathymetric image of submarine landforms, interpreted as subglacial bedforms, East Shiant Bank, central Minch. Data collected by Maritime \& Coastguard Agency. (b) Greyscale hill-shaded multibeam image showing detail of classical-shaped drumlins near southern edge of image. (c) Greyscale hill-shaded multibeam image of strongly ice-flow aligned streamlined grooves and flutes in an area of rugged bedrock seafloor geomorphology, near the Shiant Islands. (d) Hill-shaded multibeam bathymetric image of large moraine complex, and superimposed minor moraines, offshore Greenstone Point and Loch Ewe, eastern Minch. Merged MBES dataset: southern half collected by BGS (multibeam acquisition system Geoswath, Frequency 125 kHz, Grid-cell size $5 \mathrm{~m}$ ); northern half collected by Maritime \& Coastguard Agency (multibeam acquisition system Reson Seabat, Frequency 400 kHz, Grid-cell size 4m). (c) Greyscale hill-shaded multibeam image of wellpreserved seafloor ploughmarks, the product of iceberg scouring, central Minch. No vertical exaggeration. Multibeam acquisition system Reson Seabat. Frequency 400 kHz. Grid-cell size 4 m. [Contains Maritime \& Coastguard Agency MBES data.] Figures (2a-e) modified from Bradwell \& Stoker (2015a).

Figure 3. (a) Main Quaternary depocentres in the Minch and on the NW UK continental shelf and slope (modified from Stoker \& Bradwell, 2005). The line of the geo-seismic transect (d) is also shown. (b) Hill-shaded singlebeam echosounder bathymetric image (Olex dataset) showing the geomorphology of the northern Hebrides Shelf and the Sula Sgeir Fan. Numerous singlebeam echosounder acquisition systems. The margins of the cross-shelf trough are dashed. Large broad moraine ridge (North Minch Ridge) crossing the trough is labelled NMR. (c) Image showing processed seismic first-return (seabed surface) data from the shelf slope, highlighting the surface debris lobes and gulleys on the Sula Sgeir Fan. Numerous acoustic profiler acquisition systems. Surface model hill-shaded with illumination from the NE. (d) Geoseismic transect across the northern Hebrides Shelf and adjacent slope showing the glacial stratigraphic architecture of the middle to upper Pleistocene succession and age of the underlying bedrock. VE $\times 57$. Inset shows detail of glacial diamicton architecture and buried mega-scale glacial lineation surfaces on mid-shelf. VE $\times 14$. (e) BGS airgun profile across the outer continental shelf and slope showing the seismic architecture of the Sula Sgeir Fan. VE $\times 17$. Acoustic profile acquisition system BGS airgun. Filter passband 70-150 Hz. Figures (3a, d, e) modified from Stoker \& Bradwell (2005); (3b, c) modified from Bradwell \& Stoker (2015a).

Figure 4. (a) Summary map showing the spatial distribution of submarine landforms associated with the Minch palaeo-ice stream, NW Scotland. Bathymetric contours at $100 \mathrm{~m}$ vertical intervals. (b) Schematic landform-assemblage model for the fjordshelf-slope palaeo-ice stream system in NW Scotland and on the adjacent continental shelf. The legend in (a) is also applicable to (b).

\section{References}

ALLEY, R.B., CLARK, P.U., HUYBRECHTS, P. \& JOUGHIN, I. 2005. Ice-sheet and sea-level changes. Science 310, $456-460$.

BALLANTYNE, C.K. \& STONE, J. 2011. Did large ice caps persist on low ground in NW Scotland during the Lateglacial interstade? Journal of Quaternary Science 27, 297-306.

BENN, D. I. \& EVANS, D. J. A. 2010. Glaciers and Glaciation, (2 ${ }^{\text {nd }}$ Edition), 802 pp, Hodder.

BRADWELL, T., STOKER, M. \& LARTER, R. 2007. Geomorphological signature and flow dynamics of the Minch palaeo-ice stream, NW Scotland. Journal of Quaternary Science 22, 609-617.

BRADWELL, T., FABEL, D., STOKER, M.S., MATHERS, H., MCHARGUE, L. \& HOWE, J.A. 2008a. Ice caps existed throughout the Lateglacial Interstadial in northern Scotland. Journal of Quaternary Science 23, 401-407.

BRADWELL, T., STOKER, M.S., GOLLEDGE, N.R., WILSON, C.K., MERRITT, J.W., LONG, D., EVEREST, J.D., HESTVIK, O.B., STEVENSON, A.G., HUBBARD, A.L., FINLAYSON, A.G. \& MATHERS, H.E. 2008b. The northern sector of the last British Ice Sheet: Maximum extent and demise. Earth-Science Reviews 88, 207-226. 
BRADWELL, T., STOKER, M.S. 2015a. Submarine landform and sediment record of a palaeo-ice stream within the former British-Irish Ice Sheet. Boreas 44, 255-276.

BRADWELL, T., STOKER, M.S. 2015b. Asymmetric ice-sheet retreat pattern around northern Scotland revealed by marine geophysical surveys. Earth and Environmental Science, Transactions of the Royal Society of Edinburgh, 105, 297-322.

CLARK, C.D. 1993. Mega-scale glacial lineations and cross-cutting ice-flow landforms. Earth Surface Processes \& Landforms 18, 1-19.

CLARK, C.D., HUGHES, A.L.C., GREENWOOD, S.L., JORDAN, C. \& SEJRUP, H.P. 2012. Pattern and timing of retreat of the last BritishIrish Ice Sheet. Quaternary Science Reviews 44, 112-146.

DOWDESWELL, J.A., COFAIGH, C. Ó., NOORMETS, R., LARTER, R.D., HILLENBRAND, C.-D., BENETTI, S., EVANS, J. \& PUDSEY, C.J. 2008. A major trough-mouth fan on the continental margin of the Bellingshausen Sea, west Antarctica: the Belgica fan. Marine Geology 252, $129-140$.

DOWDESWELL, J. A., EVANS, J. \& Ó COFAIGH, C. 2010. Submarine landforms and shallow acoustic stratigraphy of a 400 km-long fjordshelf-slope transect, Kangerlussuaq margin, East Greenland. Quaternary Science Reviews 29, 3359-3369.

DOWDESWELL, J. A., HOGAN, K. A., Ó COFAIGH, C., FUGELLI, E. M. G., EVANS, J. \& NOORMETS, R. 2014. Late Quaternary ice flow in a West Greenland fjord and cross-shelf trough system: submarine landforms from Rink Isbrae to Uummannaq shelf and slope. Quaternary Science Reviews 92, 292-309.

EVEREST, J.D., BRADWELL, T., STOKER, M.S. \& DEWEY, S. 2013. New age constraints for the maximum extent of the last British-Irish Ice Sheet (NW Sector). Journal of Quaternary Science, 28: 2-7.

FYFE, J.A., LONG, D. \& EVANS, D. 1993. United Kingdom offshore regional report: the geology of the Malin-Hebrides Sea area. (London: HMSO for the British Geological Survey).

GALES, J.A., FORWICK, M., LABERG, J.S., VORREN, T.O., LARTER, R.D., GRAHAM, A.G.C., BAETEN, N.J. \& AMUNDSEN, H.B. 2014. Arctic and Antarctic submarine gullies - a comparison of high-latitude continental margins. Geomorphology 201, 449-461.

GIBBARD, P.L. \& CLARK, C.D. 2011. Pleistocene Glaciation Limits in Great Britain. Developments in Quaternary Science 15, 75-93.

GRAHAM, D.K., HARLAND, R., GREGORY, D.M., LONG, D. \& MORTON, A.C 1990. The biostratigraphy and chronostratigraphy of BGS Borehole 78/4, North Minch. Scottish Journal of Geology 26, 65-75.

HANNA, E., NAVARRO, F.J., PATTYN, F. \& 10 others. 2013. Ice sheet mass balance and climate change. Nature 498, 51-59.

HJELSTUEN, B.O., HAFLIDASON, H., SEJRUP, H.P. \& LYSÅ, A. 2009. Sedimentary processes and depositional environments in glaciated fjord systems - Evidence for Nordfjord, Norway. Marine Geology 258, 88-99.

HUbBard, A., BRAdWEll, T., GOlLEdGe, N.R., HALL, A.M., PATTON, H., SUGDEN, D.E.,COOPER, R. \& STOKER, M.S. 2009. Dynamic cycles, ice streams and their impact on the extent, chronology and deglaciation of the British-Irish ice sheet. Quaternary Science Reviews 28, 758-776.

KING, E. C., HINDMARSH, R. C. A. \& STOKES, C. R. 2009. Formation of mega-scale glacial lineations observed beneath a West Antarctic ice stream. Nature Geoscience 2, 585-588.

Ó COFAIGH, C., PUDSEY, C. J., DOWDESWELL, J. A. \& MORRIS, P. 2002. Evolution of subglacial bedforms along a paleo-ice stream, Antarctic Peninsula continental shelf. Geophysical Research Letters 29 (8), 10.1029/2001GL014488, 41 (1-4).

Ó COFAIGH, C., TAYLOR, J., DOWDESWELL, J. A. \& PUDSEY, C. J. 2003. Palaeo-ice streams, trough mouth fans and high-latitude continental slope sedimentation. Boreas 32, 37-55

SCHOOF, C. 2012 Marine ice sheet instability. Journal of Fluid Mechanics 698, 62-72.

SHAW, J., PIPER, D.J.W., FADER, G.B.J., KING, E.L., TODD, B.J., BELL, T., BATTERSON, M.J. \& LIVERMAN, D.G.E. 2006. A conceptual model of the deglaciation of Atlantic Canada. Quaternary Science Reviews 25, 2059-2081.

SHEPHERD, A., IVINS, E.R., GERUO, A. \& 44 others. 2012. A reconciled estimate of Ice-Sheet Mass Balance. Science 338: 1183-1189.

STOKER, M. S. 1995. The influence of glacigenic sedimentation on slope-apron development on the continental margin off northwest Britain. In: SCRUTTON, R. A., STOKER, M. S., SHIMMIELD, G. B. \& TUDHOPE, A. W. (eds), The Tectonics, Sedimentation and Palaeoceanography of the North Atlantic Region. Geological Society, London, Special Publications 90, 159-177.

STOKER, M. S. 2013. Cenozoic sedimentary rocks. In: HITCHEN, K., JOHNSON, H. \& GATLIFF, R.W. (eds), Geology of the Rockall Basin and adjacent areas. British Geological Survey Research Report, RR/12/03, 96-137.

STOKER, M.S. \& BRADWELL, T. 2005. The Minch palaeo-ice stream, NW sector of the British-Irish ice sheet. Journal of the Geological Society, London 162, 425-428.

STOKER, M.S., HITCHEN, K. \& GRAHAM, C.G. 1993. United Kingdom offshore regional report: the geology of the Hebrides and West Shetland shelves, and adjacent deep-water areas. (London: HMSO for the British Geological Survey). 


\section{T. BRADWELL, M.S. STOKER}

STOKER, M.S., BRADWELL, T., WILSON, C.K., HARPER, C., SMITH, D. \& BRETT, C. 2006. Pristine fjord landsystem revealed on the seabed in the Summer Isles region, NW Scotland. Scottish Journal of Geology 42, 89-99.

STOKER, M.S., BRADWELL, T., HOWE, J.A., WILKINSON, I.M. \& MCINTYRE, K. 2009. Lateglacial ice cap dynamics in NW Scotland: evidence from the fjords. Quaternary Science Reviews 28, 3161-3184.

STOKER, M.S., WILSON, C.R., HOWE, J.A., BRADWELL, T. \& LONG, D. 2010. Paraglacial slope instability in Scottish fjords: an example from Little Loch Broom, NW Scotland. In: HOWE, J., AUSTIN, W., FORWICK, M. \& PAETZEL, M. (eds.) Fjord Systems and Archives. Geological Society of London, Special Publication 344, 225-242.

STOKER, M.S., BALSON, P.S., LONG, D. \& TAPPIN, D.R. 2011. An overview of the lithostratigraphical framework for the Quaternary deposits on the United Kingdom continental shelf. British Geological Survey Research Report RR/11/03, 28 pp. British Geological Survey, Keyworth.

STOKES, C.R., SPAGNOLO, M. \& CLARK, C.D. 2011. The compositions and internal structure of drumlins: complexity, commonality and implications for a unifying theory of their formation. Earth Science Reviews, 107, 398-422.

SYVITSKI, J.P.M. \& SHAW, J. 1995. Sedimentology and Geomorphology of Fjords. In PERILLO, G.M.E. (ed) Geomorphology and Sedimentology of Estuaries. Developments in Sedimentology 53, Elsevier Science BV, Amsterdam, 113-178.

THIERENS, M., PIRLET, H., COLIN, C., LATRUWE, K., VANHAECKE, F., LEE, J.R., STUUT, J.-B., TITSCHACK, J., HUVENNE, V.A.I., DORSCHEL, B. WHEELER, A.J. \& HENRIET, J.-P. 2012. Ice-rafting from the British-Irish ice sheet since the earliest Pleistocene (2.6 million years ago): implications for long-term mid-latitudinal ice-sheet growth in the North Atlantic region. Quaternary Science Reviews 44, 229-240.

VAN LANDEGHEM, K.J.J., WHEELER, A.J. \& MITCHELL, N.C. 2009. Seafloor evidence for palaeo-ice streaming and calving of the grounded Irish Sea Ice Stream: implications for the interpretation of its final deglaciation phase. Boreas 38, 119-131.

VORREN, T.O. \& LABERG, J.S. 1997. Trough mouth fans - palaeoclimate and ice-sheet monitors. Quaternary Science Reviews 16, 865-881. 


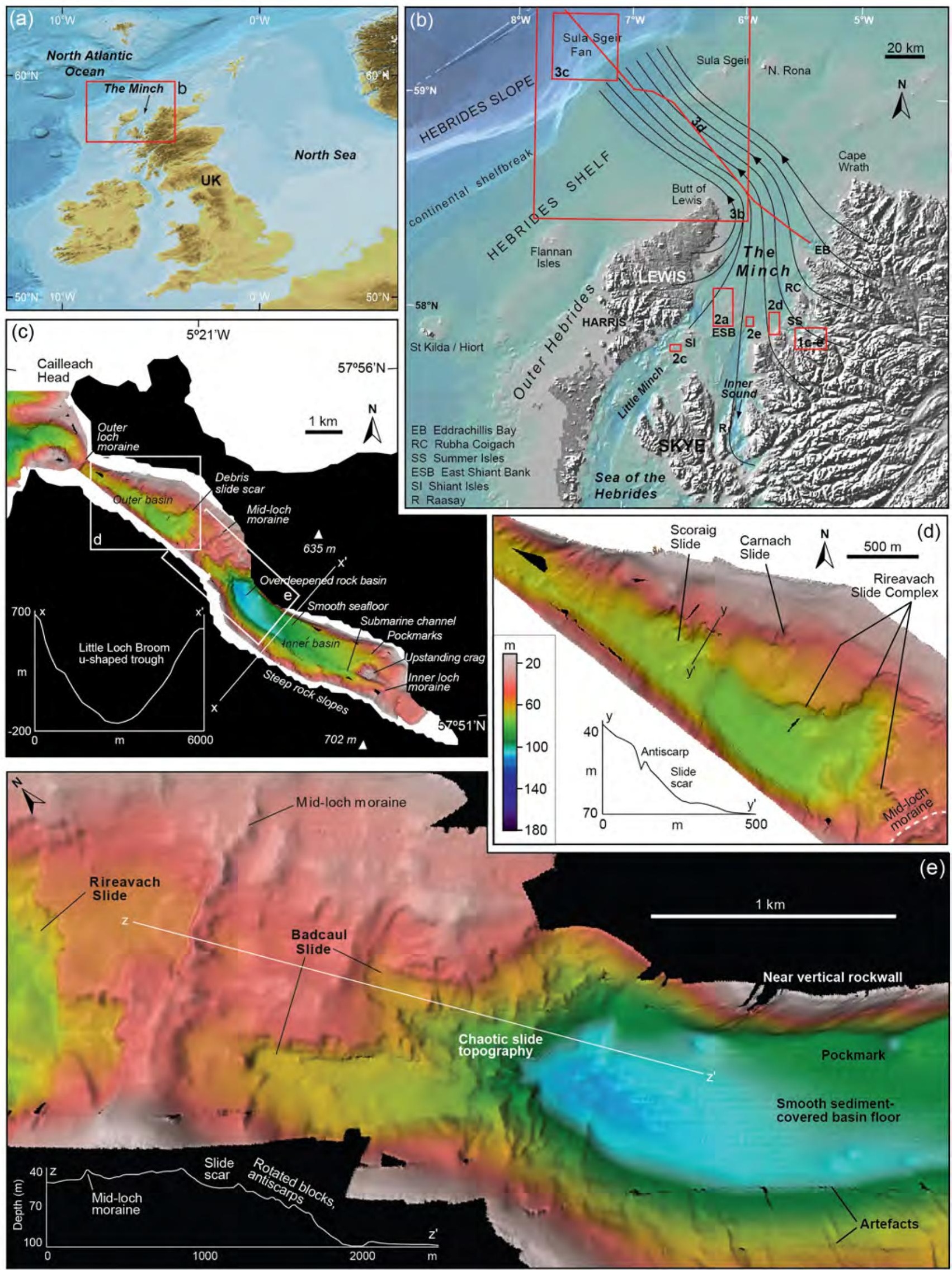




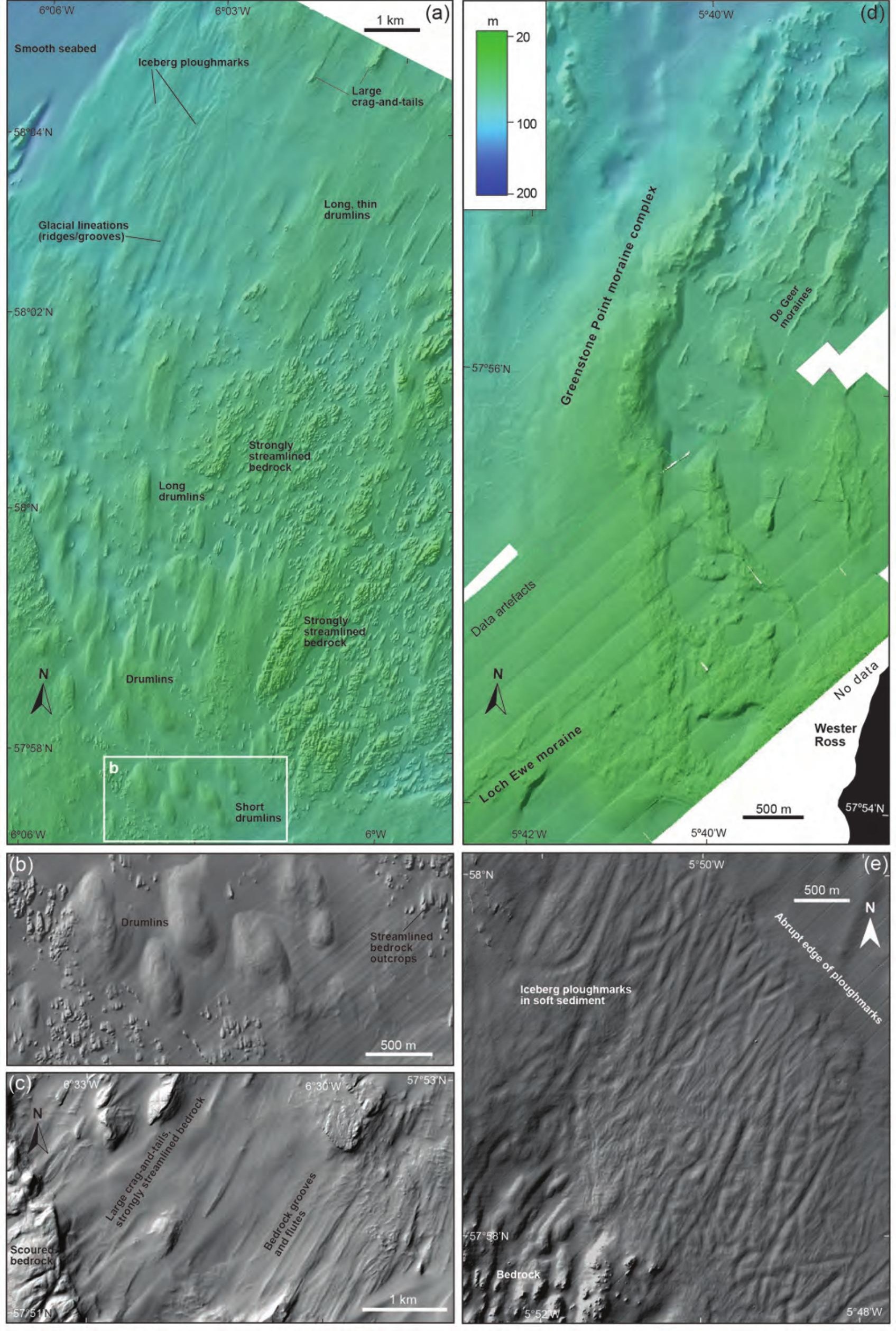


